The Bangladesh Veterinarian (2019) 36(1 - 2): 20 - 24

\title{
Prevalence of lactic acidosis in cattle and treatment response in Dinajpur district
}

\author{
BN Roy, MF Islam and BF Zohara* \\ Department of Medicine, Surgery and Obstetrics, Faculty of Veterinary and Animal \\ Science, Hajee Mohammad Danesh Science and Technology University, Dinajpur-5200, \\ Bangladesh
}

\begin{abstract}
Cattle admitted as outpatients at the Upazila (Sub-district) Veterinary Hospital in Dinajpur district headquarter and adjacent farms were examined clinically for lactic acidosis, observing loss of appetite, rumen hypo-motility or atony, dehydration, acidaemia, diarrhoea, depression, incoordination, collapse, and recumbency in severe cases. Out of 424 cattle examined, 21 were diagnosed as lactic acidosis and were categorized on the basis of sex, breed and age. Affected animals were grouped into three. Group A was treated with stomachic mixture/sodium bicarbonate orally (Zymovet ${ }^{(R)}$ Each sachet contains Ammonium Bicarbonate 5 gm, Sodium Bicarbonate 13 gm, Nux vomica 1.4 gm, Ginger Powder 300 mg, Gentian Powder 300 mg: The ACME Laboratories, Veterinary Division, Dhamrai, Dhaka, Bangladesh) and purgatives; Group B was treated with stomachic mixture/sodium bicarbonate orally and parenterally. Group $\mathrm{C}$ was treated with stomachic mixture/sodium bicarbonate orally and parenterally with antibiotic (oxytetracycline). The prevalence of lactic acidosis in indigenous and crossbred animals was 4.4 and $7.3 \%$, respectively. Group C animals recovered more quickly. It is suggested that encouraging intake of hay or straw just before and after a concentrate meal will reduce the prevalence. (Bangl. vet. 2019. Vol. 36, No. 1 - 2, 20 - 24)
\end{abstract}

\section{Introduction}

Many ruminants suffer from ruminal acidosis due to improper feeding resulting from lack of knowledge. Ruminal acidosis occurs when ruminants ingest large amounts of rapidly fermentable carbohydrates, such as finely ground corn or wheat (Beauchemin et al., 2009). This may happen in feedlots where cattle are suddenly introduced to total concentrate diets from high roughage feeds (Divers et al., 2008).

Some farmers fatten cattle and goats 3-4 months before Eid-Ul-Azha and many cases of ruminal acidosis are reported then (Sarma et al. 2011). Lactic acidosis can be called grain overload, grain poisoning, acute carbohydrate engorgement, rumen overload, acute rumenitis, toxic indigestion, or rumen acidosis. Cattle kept for fattening and post parturient cows are mostly affected. In some cases, the animals are fed stale rice, boiled rice, wheat bran, rice polish, broken rice, rice gruel, cooked rice or other

*Corresponding author:- E-mail: begumfatemafatema@ymail.com

DOI: https://doi.org/10.3329/bvet.v36i1-2.55746 
concentrates. Lactic acidosis involves increased production of lactic acid in the rumen. The severity depends on the extent of lactic acid production. Clinical manifestations range from loss of appetite to death. Lactic acid accumulates when the rumen bacteria multiply and produce more volatile fatty acids, which stimulate growth of Streptococcus bovis and Lactobacillus spp. These organisms produce large quantities of lactic acid, which reduces rumen $\mathrm{pH}$ to below 6, reducing growth of other rumen microbes that digest fibre. It may also cause laminitis (Nocek, 1997), butter fat depression (Cooper, 2013), and reduced milk protein and profuse vaginal mucus discharge (Alam, 2009). In order to reduce the prevalence of lactic acidosis it is important to feed cattle correctly. The present study was undertaken to evaluate the prevalence of lactic acidosis in cattle in Dinajpur district, the risk factors and the efficacy of treatments.

\section{Materials and Methods}

\section{Study area and period}

The study was carried out at Upazila (Sub-district) Veterinary Hospital in Dinajpur district and in nearby farms from January to May 2018.

\section{Diagnosis of lactic acidosis cases}

The malady was diagnosed mainly by means of clinical history, physical examination, and clinical signs. Close inspection was performed in order to observe loss of appetite, rumen hypo-motility or atony, dehydration, acidaemia, diarrhoea, depression, incoordination, collapse, recumbency and death. Temperature was recorded and rumen motility was examined with the help of stethoscope and manually with closed fist on the left flank. Skin fold test was performed for estimation of dehydration.

Prevalence was calculated as number of cases of disease divided by population at risk multiplied by 100 .

\section{Animals used and data collection}

Cattle were presented as outpatients at the Veterinary Hospital or visited on nearby farms. A total of 424 animals were presented in which lactic acidosis were diagnosed in 21. These animals were grouped on the basis of sex, breed and age.

Affected animals were grouped into three. Group A was treated with stomachic mixture/sodium bicarbonate orally (Zymovet) ${ }^{(\mathrm{R})}$. Each sachet contained Ammonium Bicarbonate 5 gm, sodium bicarbonate 13 gm, Nux vomica 1.4 gm, Ginger Powder 300 mg, Gentian Powder 300 mg: The ACME Laboratories, Veterinary Division, Dhamrai, Dhaka, Bangladesh) and purgatives. Group B was treated with stomachic mixture/ sodium bicarbonate orally and parenterally. Group C was treated with stomachic 
mixture/sodium bicarbonate orally and parenterally and antibiotic (oxytetracycline). Supportive treatment was given as electrolyte, vitamin-B and antihistaminic drug.

\section{Statistical analysis}

All collected data were put into Microsoft Excel program to calculate prevalence. Data were analysed by Chi-square $\left(\chi^{2}\right)$ test using IBM SPSS version 20.

\section{Results and Discussion}

\section{Prevalence of lactic acidosis in cattle}

Among the 424 cattle examined 21 were affected with lactic acidosis. Prevalence of lactic acidosis in relation with sex, breed, and age are presented in Table 1.

Table 1: Prevalence of lactic acidosis in cattle with sex, breed, and age

\begin{tabular}{|c|c|c|c|c|c|c|}
\hline Categories & Variables & +ve cases & -ve cases & $\begin{array}{c}\text { Prevalence } \\
(\%)\end{array}$ & $\begin{array}{c}\text { Chi square } \\
\text { value }\end{array}$ & $\begin{array}{c}\text { Level of } \\
\text { significance }\end{array}$ \\
\hline Cattle & $\begin{array}{l}\text { Total } \\
(\mathrm{n}=424)\end{array}$ & 21 & 403 & 5.0 & & \\
\hline \multirow[t]{2}{*}{ Sex } & $\begin{array}{l}\text { Male } \\
(\mathrm{n}=114)\end{array}$ & 9 & 105 & 7.9 & 2.867 & NS \\
\hline & $\begin{array}{l}\text { Female } \\
(\mathrm{n}=310)\end{array}$ & 12 & 298 & 3.8 & & \\
\hline \multirow[t]{2}{*}{ Breeds } & $\begin{array}{l}\text { Indigenous } \\
(\mathrm{n}=342)\end{array}$ & 15 & 327 & 4.4 & 1.207 & NS \\
\hline & $\begin{array}{l}\text { Crossbred } \\
(\mathrm{n}=82)\end{array}$ & 6 & 76 & 7.3 & & \\
\hline \multirow[t]{2}{*}{$\begin{array}{l}\text { Age groups } \\
\text { in male }\end{array}$} & $\begin{array}{l}1-3 \text { years } \\
(\mathrm{n}=84)\end{array}$ & 7 & 77 & 8.3 & 0.084 & NS \\
\hline & $\begin{array}{l}4-6 \text { years } \\
(\mathrm{n}=30)\end{array}$ & 2 & 28 & 6.7 & & \\
\hline \multirow[t]{3}{*}{$\begin{array}{l}\text { Age groups } \\
\text { in female }\end{array}$} & $\begin{array}{l}1-3 \text { years } \\
(\mathrm{n}=68)\end{array}$ & 2 & 66 & 2.9 & 0.339 & NS \\
\hline & $\begin{array}{l}4-6 \text { years } \\
(\mathrm{n}=182)\end{array}$ & 8 & 174 & 4.4 & & \\
\hline & $\begin{array}{l}>6 \text { years } \\
(\mathrm{n}=60)\end{array}$ & 2 & 58 & 3.3 & & \\
\hline
\end{tabular}

NS- Not significant $(\mathrm{P}>0.05)$

The prevalence in males was $7.9 \%$ and in females $3.8 \%$. The prevalence among indigenous and crossbred animals was 4.4 and 7.3\%, respectively. In male cattle 1 - 3 
years of age, the prevalence was $8.3 \%$ and, in those $4-6$ years of age $6.7 \%$. In females, there were no significant differences $(\mathrm{P}>0.05)$. None of the differences were significant.

There were no significant differences in the prevalence among the sex, breeds and age of animals and these findings agree with Radostits et al. (2006), who reported such cases in all types of ruminants.

\section{Treatment responses in relation to different drugs}

Responses to different treatment are shown in Table 2. In group A, the animals took six days to be fully recovered whereas animals in group $B$ recovered within five days and in group $\mathrm{C}$ within four days.

Table 2: Response to treatment in relation to different drugs

\begin{tabular}{ll|c|c|c}
\hline \multicolumn{1}{c|}{ Groups } & Drugs used for treatment & $\begin{array}{c}\text { Positive } \\
\text { response }\end{array}$ & $\begin{array}{c}\text { Response to } \\
\text { treatment (days) }\end{array}$ & Negative response \\
\hline $\begin{array}{l}\text { Group A } \\
(\mathrm{n}=7)\end{array}$ & $\begin{array}{l}\text { stomachic } \\
\text { mixture/sodium } \\
\text { bicarbonate orally and } \\
\text { purgatives }\end{array}$ & 7 & 6 days & 0 \\
\hline $\begin{array}{l}\text { Group B } \\
(\mathrm{n}=7)\end{array}$ & $\begin{array}{l}\text { stomachic mixture/ } \\
\text { sodium bicarbonate orally } \\
\text { and parenterally }\end{array}$ & 6 & 5 days & $\begin{array}{c}1 \text { (Condition of } \\
\text { animal deteriorated } \\
\text { and subsequently } \\
\text { slaughtered) }\end{array}$ \\
\hline $\begin{array}{l}\text { Group C } \\
(\mathrm{n}=7)\end{array}$ & $\begin{array}{l}\text { stomachic mixture/ } \\
\text { sodium bicarbonate orally } \\
\text { and parenterally and } \\
\text { antibiotic (oxytetracycline) }\end{array}$ & 7 & 4 days & 0 \\
\hline
\end{tabular}

The outcome of treatment with oral and systematic alkalizer with antibiotic (oxytetracycline) and symptomatic treatments was effective. Out of 21 affected animals 20 recovered and one deteriorated and was advised for slaughtering. These results conform to the result of Afonso et al. (2002) who reported that clinical recovery of animals depends on the rumen $\mathrm{pH}$. Both ruminal and systemic alkalizer were effective treatment against ruminal acidosis and the findings had similarities with Khafipour et al. (2009). On the other hand, Radostits et al. (2006) suggested using ruminal antacids orally to neutralize the ruminal acids, and intravenous hypertonic sodium bicarbonate to neutralize systemic acidosis and correct dehydration. From the above correlation between rumen fluid and blood $\mathrm{pH}$ of different cases in relation to duration of illness, treatment with ruminal and systemic alkalizer were recommended. 


\section{Conclusions}

The prevalence of acidosis in cattle was 5.0\%. Animals treated with sodium bicarbonate orally with antibiotic parenterally recovered more quickly than those given only oral antacids. Feeding strategies that prevent the onset of acidosis include encouraging intake of sufficient quantities of forage, feeding hay and/or straw just before and after concentrate meal.

\section{References}

Afonso JAB, Ciarlini PC, Kuchembuck MRG, Kohayagawa A, Feltrin LPZ, Ciarlini LDRP, Laposy CB, Mendonca CL, Takahira RK 2002: Neutrophil oxidative metabolism of sheep treated with monensin and experimentally subjected to rumen acidosis. Brazilian Journal of Veterinary Research 22 129-134.

Alam MGS 2009: Nutrition and Health: Nutrition and Health Management. In: Handbook of Dairy Nutrition -Bangladesh. Edn by Peter HR and Krishnamoorty U. Published by American Soybean Association - International Marketing, Kishan Garh, Vasant Kunj, New Delhi, India pp. 196-207.

Beauchemin K, Penner G 2009: New developments in understanding ruminal acidosis in dairy cows. Tri-State Dairy Nutrition Conference, 21-22 April, 1-12.

Cooper RL 2013: Investigating butterfat depression in dairy cows. Cattle Practice 21235.

Divers TJ, Peek SF 2008: Diseases of Dairy Cattle: Noninfectious diseases of the gastrointestinal tract. $2^{\text {nd }}$ ed., Missouri, Saunders, 130-199.

Kamaruddin KM 2003: Controlling Grass Tetany in Livestock. Cooperative Extension Service. College of Agriculture and Home Economics. New Mexico State University Guide B-809.

Khafipour E, Shucong L, Plaizier JC, Krause DO 2009: Rumen microbiome composition determined using two nutritional models of sub-acute ruminal acidosis. Applied Environment Microbiology 75 7115-7124.

Nocek JE 1997: Bovine Acidosis: Implications on Laminitis. Journal of Dairy Science 80(5) 1005-1028.

Nogues A 2013: Sub-Acute Ruminal Acidosis (SARA). http://www.ecow.co.uk/subacute-ruminal-acidosis-sara/. Accessed on 07-12-2013.

Radostits OM, Gay CC, Blood DC, Hinchcliff KW, Constable PD 2006: Diseases of the alimentary tract. In Veterinary Medicine, 10 th ed., Saunders, Edinburg 169-250.

Sarma PK, Ahmed JU 2011: An economic study of small-scale cattle fattening enterprise of Rajbari district. Journal of Bangladesh Agricultural University 9 141-146. 